$\xi=-1$

\title{
Geosynthetics reinforced flexible pavement: review of laboratory model studies
}

\author{
G.S.Ingle ${ }^{1} *$, S.S.Bhosale ${ }^{2}$ \\ ${ }^{1}$ Research Scholar in Civil Engineering Department College of Engineering Pune, India \\ ${ }^{2}$ Professor in Civil Engineering Department College of Engineering Pune, India \\ *Corresponding author E-mail: ganeshsingle@yahoo.co.in
}

\begin{abstract}
Number of laboratory studies; have shown that geosynthetics reinforcement improves the performance of flexible pavement either by extending the service life or by savings in base course thickness. In spite of the good laboratory evidence for the geosynthetics reinforced flexible pavement, the mechanism that enables and governs the reinforcement function is still unclear [1]. Cyclic laboratory test has been one of the ways, used for assessing/evaluating the soil-geosynthetic interaction mechanisms. In such a tests contribution of geosynthetics properties, interface shear provided by geotextiles and interlocking provided by geogrids when used under or within the base course of flexible pavement are mainly concentrated. This paper reviews literature of laboratory model studies carried out by various researchers over the globe. This review indicates that, appreciable improvement due to geosynthetics reinforcement depends upon various factors viz. location of geosynthetics, geogrid aperture size, geosynthetics properties, mainly stiffness, variation of base course thickness and strength of subgrade soil. The findings of these laboratory studies are also correlated with the same nature of field studies finding.
\end{abstract}

Keywords: Geosynthetics; Cyclic Loading; Reinforced Pavement; Testing Set Up; Reinforcement Mechanism.

\section{Introduction}

The performance of geosynthetics reinforced flexible pavements can be carried out by using field tests, laboratory tests and numerical simulations. These three methods not only differ widely, but have also provided different perspectives on performance data [1]. Full-scale tests include field studies and accelerated pavement tests (APT), where the field test simulates actual pavement behavior, but it takes a long testing period also it could be difficult and unsafe to close lanes on in-service roads for inspection. APT can reduce the testing period but due to its large size and the associated high cost, a limited number of pavement sections can be tested for a year, This situation can very well be changed for laboratory test; because the laboratory test can reduce the testing period as well as it is cheaper than field test, and it can be performed under controlled conditions. However, for small-scale laboratory test, it has been difficult to replicate the actual behavior of the pavement system, but a large-scale laboratory testing facility can be capable of simulating the actual pavement behavior. Finally, numerical studies have been conducted to simulate both field and laboratory tests but numerical simulations are particularly suitable for parametric evaluations. The large-scale cyclic load testing facility can be used for testing pavement sections of different base materials, different subgrade conditions, different cross sections, and different loading conditions, as well as, it can be used for other pavement and geotechnical applications such as testing new materials/products, new stabilizing techniques, and new design methodologies.

\section{Confined laboratory tests for geosynthetics reinforced pavement}

A number of laboratory tests have been proposed by various researchers for characterizing the behavior of geosynthetics reinforcement in flexible pavements. These tests include the cyclic plate load test, cyclic triaxial test, cyclic pullout test, bending stiffness test, modified pavement analyzer test, and the pullout stiffness test [2].The main features and relative merits of the various laboratories confined tests are summarized in Table 1. This paper focuses on studies involving laboratory-scale experiments using stationary cyclic plate loads.

\subsection{Cyclic plate load test}

Cyclic plate loading test has been successfully demonstrated the effect of soil confinement and dynamic loading [8].The test sections have generally consisted of laboratory reinforced, and unreinforced pavement sections constructed in a test box and were cyclically loaded to simulate construction traffic, and the performance response is assessed in terms of the magnitude of rutting with a number of loading cycles [9]. However, the facilities of cyclic plate loading tests are not readily available in public or private agencies, that need to be fabricated hence they are mainly used as a research tool in very limited universities and research institutes thus restricting the application of this test to research studies [7] .

Cyclic plate load testing facility has been developed and used worldwide for observing the performance of geosynthetics reinforced pavement, especially since from 1987 some of the recent cyclic load studies developed by various researchers with their test 
configuration and special features of the model are presented below in Table 2

Table 1: Features of Confined Laboratory Tests [1]

\begin{tabular}{|c|c|c|c|c|c|c|}
\hline Test Type & $\begin{array}{l}\text { Cyclic } \\
\text { plate load } \\
\text { test }\end{array}$ & $\begin{array}{l}\text { Cyclic triaxial } \\
\text { test }\end{array}$ & $\begin{array}{l}\text { Cyclic pullout } \\
\text { test }\end{array}$ & $\begin{array}{l}\text { Bending stiffness } \\
\text { test }\end{array}$ & $\begin{array}{l}\text { Modified as- } \\
\text { phalt pavement } \\
\text { analyzer }\end{array}$ & $\begin{array}{l}\text { Pullout Stiffness } \\
\text { Test }\end{array}$ \\
\hline Loading type & Cyclic & Cyclic & Cyclic & Cyclic & Moving wheel & \multirow{3}{*}{$\begin{array}{l}\text { Monotonic } \\
\text { Moderate } \\
\text { No }\end{array}$} \\
\hline Ease of running test & Difficult & Difficult & Moderate & Moderate & Easy & \\
\hline Control section & Yes & Yes & No & Yes & Yes & \\
\hline Repeatability of test results & - & No & No & No & Yes & Yes \\
\hline $\begin{array}{l}\text { Ability to distinguish among various } \\
\text { geosynthetics }\end{array}$ & - & No & No & No & Yes & Yes \\
\hline Design property & TBR & $\mathrm{M}_{\mathrm{R}}$ & $\mathrm{G}_{\mathrm{i}}$ & $\mathrm{BS}$ & RRR & $\mathrm{K}_{\mathrm{SGI}}$ \\
\hline References & $\begin{array}{l}\text { Perkins } \\
{[3]}\end{array}$ & $\begin{array}{l}\text { Perkins et. al } \\
\text { [4] }\end{array}$ & $\begin{array}{l}\text { Cuelho \& Per- } \\
\text { kins [5] }\end{array}$ & Sprague et. al [6] & Hanet.al [7] & Gupta [8] \\
\hline
\end{tabular}

TBR-Traffic Benefit Ratio, $\mathrm{M}_{\mathrm{R}}$ - Resilient modulus, $\mathrm{G}_{\mathrm{i}}$-Interface shear stiffness, BS -Bending stiffness, RRR- Rut reduction ratio, $\mathrm{K}_{\mathrm{SGI}}$ - Coefficient of soil-geosynthetic interaction

Table 2: Specification and Features of Each Lab Set Up

\begin{tabular}{|c|c|c|c|c|c|c|}
\hline $\begin{array}{l}\text { Researcher } \\
\text { (Year) }\end{array}$ & $\begin{array}{l}\text { Test Box size } \\
(\mathrm{m})\end{array}$ & $\begin{array}{l}\text { Test box Configura- } \\
\text { tion }\end{array}$ & $\begin{array}{l}\text { Tire } \\
\text { Simulation }\end{array}$ & $\begin{array}{l}\text { Applied Maxi- } \\
\text { mum Cyclic } \\
\text { Pressure }(\mathrm{kPa}) \\
\end{array}$ & $\begin{array}{l}\text { Loading } \\
\text { Frequency }\end{array}$ & Special Feature of the Model \\
\hline $\begin{array}{l}\text { Perkins } \\
\text { (1999) }\end{array}$ & $2.0 \times 2.0 \times 1.5$ & $\begin{array}{l}\text { 1) Side and back } \\
\text { walls of } 150 \text { mm thick } \\
\text { reinforced concrete } \\
\text { 2) Removable front } \\
\text { wall of steel channels }\end{array}$ & $\begin{array}{l}\text { Circular } \\
\text { plate, } \\
300 \mathrm{~mm} \phi\end{array}$ & 550 & $0.67 \mathrm{~Hz}$ & $\begin{array}{l}\text { In order to provide uniform pressure and } \\
\text { avoid stress concentrations along the } \\
\text { plate's perimeter (i.e., similar to a tire } \\
\text { load), a } 6 \mathrm{~mm} \text { thick, waffled butyl-rubber } \\
\text { pad is placed beneath the load plate }\end{array}$ \\
\hline $\begin{array}{l}\text { Leng et.al } \\
(2002)\end{array}$ & $1.5 \times 1.5 \times 1.35$ & $\begin{array}{l}\text { Steel walls for all } \\
\text { sides (side, back front } \\
\text { and bottom) }\end{array}$ & $\begin{array}{l}\text { Circular } \\
\text { plate } \\
305 \mathrm{~mm} \phi\end{array}$ & 550 & $0.67 \mathrm{~Hz}$ & $\begin{array}{l}\text { The selected box size was verified by } \\
\text { Gabr et. al. [16] based on the concept of } \\
\text { minimizing interference from the box } \\
\text { boundaries on the test results }\end{array}$ \\
\hline $\begin{array}{l}\text { Tanyu } \\
\text { et.al } \\
(2003)\end{array}$ & $3.0 \times 3.0 \times 3.0$ & $\begin{array}{l}\text { 1) Concrete test pit } \\
\text { below ground level } \\
\text { 2) Side wooden walls } \\
\text { above ground level up } \\
\text { to } 1.0 \mathrm{~m} \text { along the } \\
\text { boundaries of the pit }\end{array}$ & $\begin{array}{l}\text { Circular } \\
\text { plate, } \\
250 \mathrm{~mm} \phi\end{array}$ & 400 & $1.0 \mathrm{~Hz}$ & $\begin{array}{l}\text { Large scale model can replicate the field } \\
\text { condition of pavement section as closely } \\
\text { as practical by keeping the surface of the } \\
\text { subgrade soil is nearly at the top surface of } \\
\text { the test pit. }\end{array}$ \\
\hline $\begin{array}{l}\text { Bhosale } \\
\text { S.S. et.al } \\
(2008)\end{array}$ & $0.45 \times 0.20 \times 0.15$ & $\begin{array}{l}\text { Acrylics box of scale } \\
\text { factor of } 1: 7.5\end{array}$ & $\begin{array}{l}\text { Pair of } \\
\text { rectangular } \\
\text { shaped MS } \\
\text { pads of } \\
55.5 \mathrm{~mm} \mathrm{x} \\
37.5 \mathrm{~mm}\end{array}$ & 480 & - & $\begin{array}{l}\text { 1) Failure pattern of pavement could be } \\
\text { seen during experimentation. } \\
\text { 2)Mechanism for simulation of anchorage } \\
\text { of the geotextile due to surcharge of sub- } \\
\text { base/base aggregate course over subgrade } \\
\text { in the field }\end{array}$ \\
\hline $\begin{array}{l}\text { Abu Far- } \\
\text { sakh et.al } \\
(2012)\end{array}$ & $1.98 \times 1.98 \times 1.68$ & $\begin{array}{l}125.4 \mathrm{~mm} \text { thick steel } \\
\text { side and back walls } \\
\text { braced with stiffeners }\end{array}$ & $\begin{array}{l}\text { Circular } \\
\text { plate, } \\
305 \mathrm{~mm} \phi\end{array}$ & 550 & $0.77 \mathrm{~Hz}$ & $\begin{array}{l}\text { The hydraulic actuator with the crosshead } \\
\text { (loading beam) can be detached from the } \\
\text { box and moved to the field for in-situ } \\
\text { testing }\end{array}$ \\
\hline $\begin{array}{l}\text { Yu Qian } \\
\text { et.al } \\
(2013)\end{array}$ & $2.0 \times 2.2 \times 2.0$ & $\begin{array}{l}\text { Steel walls for all } \\
\text { sides (side, back front } \\
\text { and bottom) }\end{array}$ & $\begin{array}{l}\text { Circular } \\
\text { plate, } \\
300 \mathrm{~mm} \phi\end{array}$ & 550 & $0.77 \mathrm{~Hz}$ & The box is consistent with Leng et.al [10] \\
\hline $\begin{array}{l}\text { Sireesh } \\
\text { Saride } \\
\text { et.al } \\
(2015)\end{array}$ & $1.0 \times 1.0 \times 1.0$ & $\begin{array}{l}\text { Steel walls for all } \\
\text { sides (side, back front } \\
\text { and bottom) }\end{array}$ & $\begin{array}{l}\text { Circular } \\
\text { plate, } \\
150 \mathrm{~mm} \phi\end{array}$ & 440 & $0.77 \mathrm{~Hz}$ & $\begin{array}{l}\text { To check the boundary effects on the } \\
\text { experimental results strain type earth } \\
\text { pressure transducers were placed at the } \\
\text { boundaries of the tank }\end{array}$ \\
\hline
\end{tabular}

\section{Critical appraisal}

The studies discussed in the preceding sections have provided insight into the features of cyclic plate load tests and the role of geosynthetics reinforcement mechanisms in flexible pavements. Table 3 summarizes the critical specification and features of each laboratory set up. From the Table 3.0, it is found that the test box size (pavement section) selected by various investigators, varies from $3.0 \mathrm{~m} \times 3.0 \mathrm{~m} \times 3.0 \mathrm{~m}$ [11] to $0.45 \mathrm{~m} \times 0.25 \mathrm{~m} \times 0.15 \mathrm{~m}$ [12] Except Leng [10]; no other investigator provided the criteria for selection of box size. The box size may be selected as the basis of minimum interference of box boundaries. It is also noticed that the pavement sections used in most of the studies [3], [13], [14], [15] did not replicate the actual condition of unconfined asphalt layer in the majority of the field situation. Further, Table 3 shows the families of geosynthetics used by various researchers;

Table 3 indicates that, most of the researchers have given stressed only on geogrid of varying stiffness and aperture shape (biaxial or triaxial). However, the confinement effect of geogrid depends on various parameters such as rib shape, apertures size, the stiffness of the ribs, junction strength and the properties of aggregates. Except Bowman [14] no other researcher considers the effect of geogrid rib and junction strength on performance of pavement section. Furthermore, no other researcher considers the effect of base course aggregate properties (Gradation and CBR) on the reinforcement mechanism of geosynthetics.

Critical parameter observed during the test are presented in Table 4 , it is found that, the most of the researchers measure the effect of 
geosynthetics reinforcement in terms of surface deformation and vertical stress distribution at subgrade level.

The summary of major findings from various investigators is tabulated in Table 5, which highlights the comparison between different geosynthetics type with its location effect on pavement performance. From the Table 5, it is found that most of the research- ers consider the permanent deformation (Rut depth) of pavement as a performance indicator. For a given rut depth the geogrid reinforced pavement section performed better than unreinforced section, in the form of reduction of base course thickness or reduction of vertical stress distribution at subgrade level.

Table 3: Reinforcement (Geosynthetics) Used in Each Study

\begin{tabular}{|c|c|c|c|}
\hline $\begin{array}{l}\text { Researcher } \\
\text { (Year) }\end{array}$ & Geosynthetics type & Geosynthetics type \& Structure & Geosynthetics Location \\
\hline Perkins (1999) & $\begin{array}{l}\text { Geogrid A } \\
\text { Geogrid B } \\
\text { Geotextile }\end{array}$ & $\begin{array}{l}\text { Punched, drawn, biaxial (Polypropylene) } \\
\text { Punched, drawn, woven (Polypropylene) }\end{array}$ & $\begin{array}{l}\text { Base-subgrade interface } \\
\text { and } 100 \mathrm{~mm} \text { above base-subgrade inter- } \\
\text { face } \\
\text { Base-subgrade interface }\end{array}$ \\
\hline Leng et.al (2002) & $\begin{array}{l}\text { Geogrid } \\
\text { Geonet with geotextile }\end{array}$ & $\begin{array}{l}\text { Biaxial (Polypropylene) } \\
\text { Nonwoven }\end{array}$ & $\begin{array}{l}\text { Base-subgrade interface } \\
\text { Base-subgrade interface }\end{array}$ \\
\hline Bhosale S.S. et.al (2008) & Geotextile & polypropylene multifilament woven & $\begin{array}{l}\text { Base-subgrade interface } \\
\text { Base-subgrade interface }\end{array}$ \\
\hline Abu Farsakh et.al (2012) & Geogrids & Biaxial \& triaxial (polypropylene ) & $\begin{array}{l}\text { Upper one third of base course and } \\
\text { Middle of the base layer }\end{array}$ \\
\hline John R. Bowman (2012) & Geogrids & $\begin{array}{l}\text { Extruded biaxial and triaxial (Polypro- } \\
\text { pylene) }\end{array}$ & Base-subgrade interface \\
\hline Yu Qian et.al (2013) & Geogrids & Triaxial (Polypropylene) & Base-subgrade interface \\
\hline
\end{tabular}

Table 4: Measurement of Various Parameters from Test Sections

\begin{tabular}{lllll}
\hline $\begin{array}{l}\text { Researcher } \\
\text { (Year) }\end{array}$ & Surface of test Section & Base and Subbase Layers & $\begin{array}{l}\text { Geosyn- } \\
\text { thetics }\end{array}$ & Subgrade \\
\hline Perkins (1999) & Surface deformation & Radial strain & strain & $\begin{array}{l}\text { Vertical stress and strain and radial strain } \\
\text { Leng et.al (2002) }\end{array}$ \\
$\begin{array}{lll}\text { Tanyu et.al (2003) } \\
\text { Bhosale S.S. et.al (2008) }\end{array}$ & Surface deformation & Surface contours & Vertical stress, permanent deformation \\
Abu Farsakh et.al (2012) & Surface deformation & Vertical deformation & None & Vertical deformation \\
John R. Bowman (2012) & Surface deflection & Vertical displacement & strain & Vertical stress and strain \\
Yu Qian et.al (2013) & Surface deformation & None & None & Vertical displacement \\
Sireesh Saride et.al (2015) & Surface deformation & None & None & Vertical deformation \\
\hline
\end{tabular}

Except, Perkins (1999) no other investigators observed the strain developed in the asphalt concrete layer.

Table 5: Summary of the Major Finding of Each Study and Comparison with Field Studies of Similar Nature

\begin{tabular}{|c|c|c|c|c|c|c|}
\hline $\begin{array}{l}\text { Researcher } \\
\text { (Year) }\end{array}$ & $\begin{array}{l}\text { Performance } \\
\text { Criteria }\end{array}$ & $\begin{array}{l}\text { Effect of Geo- } \\
\text { synthetics type }\end{array}$ & $\begin{array}{l}\text { Effect of Geosyn- } \\
\text { thetics Location }\end{array}$ & $\begin{array}{l}\text { Subgrade } \\
\text { Strength \& Stiff- } \\
\text { ness Characteris- } \\
\text { tics }\end{array}$ & $\begin{array}{l}\text { Base course layer } \\
\text { Equivalency }\end{array}$ & $\begin{array}{l}\text { Other Observations including Field } \\
\text { studies of same nature }\end{array}$ \\
\hline $\begin{array}{l}\text { Perkins } \\
\text { (1999) }\end{array}$ & $\begin{array}{l}\text { Permanent } \\
\text { surface de- } \\
\text { formation }\end{array}$ & $\begin{array}{l}\text { Between the } \\
\text { two geogrid, } \\
\text { the stiffer one } \\
\text { exhibited better } \\
\text { performance. } \\
\text { While both } \\
\text { geogrids per- } \\
\text { formed better } \\
\text { than geotextile }\end{array}$ & $\begin{array}{l}\text { Better perfor- } \\
\text { mance was ob- } \\
\text { served when the } \\
\text { geogrid was ele- } \\
\text { vated in the base } \\
\text { (100mm up to the } \\
\text { base layer for } 300 \\
\text { mm thick.) as } \\
\text { compared to sub- } \\
\text { grade-base course } \\
\text { interface }\end{array}$ & $\begin{array}{l}\text { Geogrid showed } \\
\text { substantial im- } \\
\text { provement for } \\
\text { pavement built } \\
\text { over a subgrade } \\
\text { of CBR } 1.5 \% \text {, } \\
\text { while little im- } \\
\text { provement was } \\
\text { found for strong } \\
\text { CBR of } 20 \% \text {. }\end{array}$ & $\begin{array}{l}\text { The reinforce- } \\
\text { ment allows for } \\
\text { at least a } 20 \% \\
\text { reduction in base } \\
\text { thickness }\end{array}$ & $\begin{array}{l}\text { Reinforced test sections having a } \\
300 \text { mm-thick base with an unrein- } \\
\text { forced test section having a } 375 \\
\text { mm-thick base showed better per- } \\
\text { formance. } \\
\text { A.V.S.R. Murty et.al [17] carried } \\
\text { out a field performance study of } \\
\text { geotextile reinforced low volume } \\
\text { road from December } 1988 \text { to Febru- } \\
\text { ary } 1992 \text {. The performance study } \\
\text { shows that, geotextile reinforced } \\
\text { road are having lesser distresses as } \\
\text { compared to control section. The } \\
\text { type /variety of geotextile is not } \\
\text { having any significance on perfor- } \\
\text { mance }\end{array}$ \\
\hline $\begin{array}{l}\text { Leng et.al } \\
(2002)\end{array}$ & $\begin{array}{l}\text { Vertical } \\
\text { surface de- } \\
\text { formation }\end{array}$ & $\begin{array}{l}\text { Higher modu- } \\
\text { lus geogrids } \\
\text { provided a } \\
\text { better stress } \\
\text { attenuation } \\
\text { effect compared } \\
\text { to lower modu- } \\
\text { lus geogrids }\end{array}$ & NA & NA & NA & $\begin{array}{l}\text { The stress distribution at subgrade } \\
\text { level is lesser for higher thickness } \\
\text { ( } 245 \mathrm{~mm}) \text { of base course as com- } \\
\text { pared to lower thickness ( } 152 \mathrm{~mm}) \text {. } \\
\text { Al-Qadi I.L.et.al [18] in their eight } \\
\text { year field performance studies ob- } \\
\text { served same kind of results, that the } \\
\text { geosyntheics stabilized pavement } \\
\text { extends the service life. However } \\
\text { this increase in service life is re- } \\
\text { duced for stronger pavements } \\
\text { (Higher base thickness) }\end{array}$ \\
\hline
\end{tabular}




\begin{tabular}{|c|c|c|c|c|c|c|}
\hline $\begin{array}{l}\text { Tanyu et.al } \\
(2003)\end{array}$ & Rut depth & $\begin{array}{l}\text { The difference } \\
\text { in geocell ge- } \\
\text { ometry (diame- } \\
\text { ter and cell } \\
\text { height) did not } \\
\text { show any sig- } \\
\text { nificant differ- } \\
\text { ences in rutting } \\
\text { behavior. }\end{array}$ & NA & NA & $\begin{array}{l}\text { Geocell rein- } \\
\text { forcement effect } \\
\text { was more evident } \\
\text { in thinner ( } 225 \\
\mathrm{~mm}) \text { sections } \\
\text { than in thicker } \\
(450 \mathrm{~mm})\end{array}$ & $\begin{array}{l}\text { The presence of geocells improved } \\
\text { the resilient modulus by } 40 \text { to } 50 \% \\
\text { in both } 225 \mathrm{~mm} \text { and } 450 \mathrm{~mm} \text { thick } \\
\text { sections. }\end{array}$ \\
\hline $\begin{array}{l}\text { Bhosale S.S. } \\
\text { et.al (2008) }\end{array}$ & Rut depth & $\begin{array}{l}\text { Membrane } \\
\text { effect of geo- } \\
\text { textile will be } \\
\text { mobilized } \\
\text { lesser and less- } \\
\text { er for the geo- } \\
\text { textile of lower } \\
\text { grab/tensile } \\
\text { strength }\end{array}$ & NA & NA & NA & $\begin{array}{l}\text { The higher the stiffness of the geo- } \\
\text { textile with assured interface friction } \\
\text { the better will be the triggering up of } \\
\text { membrane action at an early stage of } \\
\text { deformation }\end{array}$ \\
\hline $\begin{array}{l}\text { Abu Farsakh } \\
\text { et.al (2012) }\end{array}$ & $\begin{array}{l}\text { Permanent } \\
\text { deformation }\end{array}$ & $\begin{array}{l}\text { Traffic Benefit } \\
\text { Ratio(TBR) } \\
\text { increased from } \\
5.5 \text { for the } \\
\text { biaxial geogrid } \\
\text { to } 6.4 \text { for the } \\
\text { triaxial geogrid } \\
\text { at } 19 \mathrm{~mm} \text { rut } \\
\text { depth) }\end{array}$ & $\begin{array}{l}\text { Better perfor- } \\
\text { mance was ob- } \\
\text { served when the } \\
\text { geogrid was } \\
\text { placed within the } \\
\text { upper one third of } \\
\text { the base aggregate } \\
\text { layer as compared } \\
\text { to the base- } \\
\text { subgrade interface } \\
\text { or at the middle of } \\
\text { the base }\end{array}$ & $\begin{array}{l}\text { The geogrid can } \\
\text { significantly } \\
\text { reduce the rut } \\
\text { depth and extend } \\
\text { the service life of } \\
\text { pavement sec- } \\
\text { tions which built } \\
\text { on weak sub- } \\
\text { grades } \\
(\mathrm{CBR} \leq 1 \%)\end{array}$ & NA & $\begin{array}{l}\text { The construction method can have a } \\
\text { significant effect on mobilizing the } \\
\text { interaction between the geogrid and } \\
\text { base course aggregates }\end{array}$ \\
\hline $\begin{array}{l}\text { John R. } \\
\text { Bowman } \\
(2012)\end{array}$ & Rut depth & $\begin{array}{l}\text { The extruded } \\
\text { geogrid per- } \\
\text { formed consist- } \\
\text { ently better } \\
\text { than the non- } \\
\text { extruded ge- } \\
\text { ogrids }\end{array}$ & NA & NA & NA & $\begin{array}{l}\text { Largest tensile strains developed } \\
\text { directly beneath the center of the } \\
\text { cyclic loading plate and became } \\
\text { negligible at a } 1.5 \mathrm{D} \text { distance from } \\
\text { the loading plate }\end{array}$ \\
\hline $\begin{array}{l}\text { Yu Qian } \\
\text { et.al (2013) }\end{array}$ & $\begin{array}{l}\text { Permanent } \\
\text { deformation }\end{array}$ & $\begin{array}{l}\text { The permanent } \\
\text { deformation for } \\
\text { heavy-duty } \\
\text { geogrid, was } \\
\text { lesser as com- } \\
\text { pared to medi- } \\
\text { um and light } \\
\text { duty geogrid }\end{array}$ & NA & NA & $\begin{array}{l}\text { The stress distri- } \\
\text { bution angle } \\
\text { increased with } \\
\text { the increase of } \\
\text { the base thick- } \\
\text { ness. }\end{array}$ & $\begin{array}{l}\text { Andrus Aavik et. al [19] carried out } \\
\text { a field performance study from } \\
2009-2013 \text { for geosynthetic } \\
\text { Reinforced road constructed in } \\
\text { swampy area in Estonia. The per- } \\
\text { formances of field trials were meas- } \\
\text { ured in the form of International } \\
\text { Roughness Index (IRI). The IRI } \\
\text { values for geosynthetics sections are } \\
\text { in average about } 6.4 \% \text { bigger than } \\
\text { IRI values of sections without geo- } \\
\text { synthetics. }\end{array}$ \\
\hline $\begin{array}{l}\text { Sireesh } \\
\text { Saride et.al } \\
(2015)\end{array}$ & $\begin{array}{l}\text { Permanent } \\
\text { deformation }\end{array}$ & $\begin{array}{l}\text { A TBR of as } \\
\text { high as } 23 \text { was } \\
\text { observed for } \\
\mathrm{h} / \mathrm{D}=1.0 \text { and } \\
\mathrm{b} / \mathrm{D}=4.33\end{array}$ & NA & NA & NA & $\begin{array}{l}\text { Avinash Unni [21] carried out a } \\
\text { field performance study of geocell } \\
\text { pavement at Govind Dairy Farm in } \\
\text { Phaltan, India. }\end{array}$ \\
\hline
\end{tabular}

\section{Concluding remark and issue to be ad- dressed}

1) Most of the above laboratory model studies have shown that appreciable reduction in surface deformation can be realized by keeping geosynthetics within the upper one third of the base course aggregate layer of a flexible pavement. This reduction was found to increase with stiffness of geogrid. It was also observed that geogrids performed better than geotextile.

2) The test box (pavement section) size varies from $3.0 \mathrm{~m} x$ $3.0 \mathrm{~m} \times 3.0 \mathrm{~m}$ [11] to $0.45 \mathrm{~m} \times 0.25 \mathrm{~m} \times 0.15 \mathrm{~m}$ [12] where the pavement sections are confined in a box, have a scaling effect. Application of results of small scale laboratory simulation to the field condition found to have limitations.

3) Majority of the studies [3], [13], [14], [15] simulated a half axle load of $40 \mathrm{kN}$, while mobilization of geosynthetics re- inforcement mechanism under the half axle load may differ as compared to the full scale standard axle load on field.

4) Most of the researchers considers the influence of geosynthetics properties mainly geogrid aperture size and stiffness on reinforced mechanism, but in practice other parameter such as geogrid rib strength, junction strength etc. will also contribute for reinforcement mechanism.

The following areas have been identified, through the re-viewed literature that needs further studies

1) Development of full scale laboratory test for which pavement section can simulate the field condition by constructing the unconfined asphalt layer and is to be tested under standard axle load.

2) The combined effect of geogrid rib strength, junction strength and base course aggregate properties on reinforcement mechanism using full scale model, needs to be studied. 


\section{Acknowledgement}

The Director, College of Engineering Pune is hereby acknowledged for permitting this research paper. Indian Institute of Technology Delhi and Indian Institute of Technology Bombay are acknowledged for providing library facility for the literature survey.

\section{References}

[1] J.G. Zornberg, R. Gupta, Geosynthetics in pavements: North American contributions 9th International Conference on Geosynthetics, Brazil, (2010).

[2] J.G.Zornberg, Advances in the use of geosynthetics in pavement design, Geosynthetics India'11, 23-24, September (2011).

[3] S.W. Perkins, Geosynthetic reinforcement of flexible pavements laboratory based pavement test sections, Federal Highway Administration Report FHWA/MT-99-001/8138, Montana Department of Transportation, Helena, Montana, USA, (1999).

[4] S.W. Perkins, B.R.Christopher, E.L. Cuelho, G.R. Eiksund, I.Hoff C.W. Schwartz, G. Svan, and A. Want, Development of design methods for geosynthetic reinforced flexile pavements, FHWADTFH61-01-X 00068, Final report, 263p, (2004).

[5] E.L. Cuelho, S.W. Perkins, Resilient interface shear modulus from short-strip cyclic pullout tests, GSP-140, Slopes and Retaining Structures under Seismic and Static Conditions, Geofrontiers, Austin, TX, (2005).

[6] C.J. Sprague, S.Lothspeich, F. Chuck, R. Goodman, Geogrid rein forcement of road base aggregate measuring the con-finement benefit, Proceedings of Geo- Trans 2004 Conference, Los Angeles, ,(2004) 996 -1005.

[7] J.Han, Y.Zhang, R.L Parsons, Development of a performancebased laboratory test method for evaluating geosynthetic-soil confinement, Geosynthetics Committee (AFS70) TRB 2008 Annual Meeting, Washington DC, (2008).

[8] R. Gupta, A Study of geosynthetic reinforced flexible pavement system, Ph.D. Dissertation, Submitted to the University of Texas at Austin, Texas, USA, (2009).

[9] C.V.S. Benjamin, B. Bueno, J.G. Zornberg, Field monitoring evaluation of geotextile-reinforced soil retaining walls, Geosynthetics International Journal, Vol.14(1), (2007).

[10] J.,Ju Leng, M.A. Gabr, Characteristics of geogrid reinforced aggregate under cyclic load, Transportation Research Record 1786,Transporattion Research Board National Research Council, Washington D.C (2002) 29-35 .

[11] B. F. Tanyu, W. H.Kim, T. B. Edil, C. H. Benson, Comparison of laboratory resilient moduli with back-calculated elastic moduli from large-scale model Experiments and FWD tests on granular materials, Resilient Modulus Testing for Pavement Components, Durham G. N., Marr, A. W. \& De Groff, W. L Editors, ASTM, West Conshohocken PA, USA, STP 1437 ( 2003) 191-208.

[12] S.S. Bhosale, B.R. Kambale, Laboratory study for evaluation of membrane effect of geotextile in unpaved road, the12th International Conference of International Association for Computer Methods and Advances in Geomechanics (IACMA), Goa, (2008).

[13] Murad Abu-Farsakh Y., Qiming Chen, Evaluation of the base/subgrade soil under repeated loading: Phase I- In-Box and ALF cyclic plate load tests, Final Report. No. FHWA/LA.09/450, Louisiana Transportation Research Center, Baton Rouge, LA, (2012).

[14] John R. Bowman, Development of ODOT guidelines for the use of geogrids in aggregate bases, FHWA Report, (2012).

[15] Yu Qian, Jie Han, Performance of triangular aperture geogridreinforced base courses over weak subgrade under cyclic loading, Journal of Materials in Civil Engineering, Vol. 25, No. 8, (2013) 1013-1021.https://doi.org/10.1061/(ASCE)MT.1943-5533.0000577.

[16] M. Gabr, Cyclic plate loading tests on geogrid reinforced roads, Research Rep. to Tensar Earth Technologies, Inc., North Carolina State Univ., Raleigh, NC, (2001)

[17] A.V.S.R. Murty, Sudhir Mathur, S. K. Soni and K. Nageswara Rao, Use of geotextiles in low volume roads, - A Case study, proceedings: Third international conference on case histories in Geotechnical Engineering, St. Louis, Missouri, (1993).

[18] Imad L. Al-Qadi and Alexander Kwasi Appea, Eight-year of field performance of a secondary road incorporating geosynthetics at the subgrade-base Interface, Transportation Research Board 82nd Annual Meeting, Washington, D.C,(2003).
[19] Andrus Aavik, Artu Ellmann,Priit Paabo, Use of Geosynthetics for Road base Strengthening- Case Study in Swampy Area, The XXVIII International Baltic Road Conference, (2013).

[20] Sireesh Saride, Rayabharapu, Vijay K., Suraj Vedpathak,Evaluation of rutting behavior of geocell reinforced sand subgrades under repeated loading, Indian Geotech. Journal, 45 (4), (2015) 378-388. https://doi.org/10.1007/s40098-014-0120-8.

[21] Avinash Unni, Structural and economic evaluation of geocell in the road pavement structure, M.Tech. Dissertation, Submitted to the Indian Institute of Chennai, India, (2010) 